\title{
Historiography of the Armed Terrorism Prevention in the Criminal Legislation of Ukraine
}

\author{
Komarynska Yuliia \\ PhD of Juridical Sciences, Associate Professor, Professor of \\ Department of Criminology and Forensic Medicine of the National Academy \\ of Internal Affairs, Kiev, Ukraine \\ ORCID ID 0000-0002-1747-1816 ubk2006@ukr.net \\ Pavlovska Nataliia \\ PhD of Juridical Sciences, Associate Professor, Professor of \\ Department of Civil Law and Process of the National Academy of Internal \\ Affairs, Kiev, Ukraine ORCID ID 0000-0003-3311-0364 \\ wwwpav@gmail.com

\section{Svoboda Eugenia} \\ PhD of Juridical Sciences, Associate Professor, Professor of Department of \\ Forensic Support and Forensic Expertise of the National Academy of \\ Internal Affairs, Kiev, Ukraine \\ ORCID ID 0000-0002-8639-8333_jeechka@ukr.net
}

\section{Symchuk Anatolii}

Senior Teacher of Forensic Support and Forensic Expertise of the National Academy of Internal Affairs, Kiev, Ukraine ORCID ID 0000-0002-8663-8210 symchukas@gmail.com

\section{Kofanova Olena}

PhD of Juridical Sciences, Associate Professor of Forensic Support and Forensic Expertise of the National Academy of Internal Affairs,

Kiev, Ukraine

ORCID ID 0000-0002-0919-7570 kofanova_alena@ukr.net

\footnotetext{
Abstract

The Ukrainian state and society, due to historical, socio-political and economic circumstances, are involved in the problems of terrorism so we should seek ways to efficiently counter terrorism, use hands-on experience of the international community, and improve our national legislation in this area.

Having political and economic relations with other states, Ukraine, in addition to the benefits of such cooperation, in some cases acquires problems and is drawn into various kinds of conflicts against its will. Sometimes such conflicts are linked to terrorism.

Rather typical in this regard is the example of attempts in the 1990s to 'bind' Ukraine to the Kurdish problem due to the residence on the territory of Ukraine of about 12 thousand Kurds (as of 1995) [1, p. 50]. In September 2004, similar attempts were made in connection with the migration of Chechens after the events in Beslan.

Keywords: terrorism, legal community but also sociology, political science, social, individual psychology, and other fields of science, historiography.
} 
Introduction At the 50th session of the UN General Assembly (1995), it was noted that with a decrease in the number of terrorist acts, the scale and danger of terrorism increases due to the use of new achievements in science and technology (modern means of communication and transport), world-class sources of financing, good knowledge of explosives and modern weapons, and an increase in transnational actions [2]. The internal restructuring of the state and society in Ukraine, changes in the principles of foreign economic and foreign policy activities, and its greater openness have become the reasons for the penetration of terrorism into the CIS and Ukraine (Commonwealth of Independent States - a regional international organization that includes a number of post-Soviet countries and Ukraine, who terminated participation in the CIS statutory bodies on 19.05.2018 subject to the Presidential Decree by P.Poroshenko. In this regard, numerous political forces in the state represented by various parties and trends to achieve their goals, have intensified the struggle for influence on the public. To this end the entire spectrum of socioeconomic, national, ethno-territorial, interreligious contradictions and other dissensions is used. Due to the socioeconomic polarization of society and increase of the downgraded, marginal strata of society, the struggle between the parties of the democratic bloc and the parties representing the interests of capital has become noticeably more acute. There are ongoing inter-confessional contradictions and conflicts in certain regions of the country.

In 1990s the law enforcement agencies of Ukraine pointed to the attempts of international terrorist groups to expand into the territory of our country. The 'transparency' of borders with the CIS countries, imperfect legislation, which regulated the procedure for foreigners' stay in Ukraine and their expulsion from the country in case of committing illegal actions, was used by members of these organizations to evade responsibility the crimes committed. In 1994-1996, several hundred people were identified and verified, with regard to their involvement in the activities of religious-extremist and terrorist organizations in the Middle East, South-East Asia, and Latin America. The Security Service of Ukraine has exposed several attempts by Middle East terrorist organizations to use Ukraine to prepare and carry out illegal actions against diplomatic missions of foreign states in the CIS and Western Europe, to accumulate arsenals of weapons and explosives. The presence in Ukraine of a significant number of refugees from the former Soviet republics with a complex political criminal situation (Russia, Georgia, Azerbaijan, Armenia, Moldova) had adverse effect on countering terrorism. 
Individuals from these countries committed acts of violence with signs of terrorism in their countries. There are attempts to use the territory of Ukraine by members of the military extreme formations of the CIS countries to hide from prosecution for committing terrorist acts, participation in military conflicts on the territory of their states [1, p. 56 ].

Military conflicts in the CIS countries and the Balkans have led to the expansion of such a negative phenomenon as illegal mercenarism in Ukraine. Specific evidences indicate that the main danger of this phenomenon is that Ukrainian citizens participating in combat operations abroad gain experience in sabotage and terrorist activities and can be used to commit crimes of the terrorist nature. Investigating the issue of terrorism V.Antipenko in his scientific works notes that the dynamics of manifestations of terrorist nature in relation to the authorities in Ukraine in the 1990s comprised more than 200 cases in 1995 (63 of them were threats against parliamentary candidates), about 200 and 100 threats in 1996 and 1997 respectively. In total, over this period, the Security Service detected 165 verbal and 233 written anonymous threats, 126 crimes were committed resulting in the death of 18 individuals and 24 injuries. In cooperation with other law enforcement agencies during this period, more than 200 manifestations of terrorist nature were detected, 31 persons were brought to criminal responsibility, and preventive measures were taken for many of them [1, p. 45]. Political confrontation in the country increases the likelihood of using terrorist methods. Moreover, paramilitary formations of various political forces such as the DSU "VARTA", the Ukrainian branch of the Russian "Red Army", organizations of the "Revolutionary Communist Youth", troops of the "Avdet" party, not excluding extremism in achieving their goals, have been operating in Ukraine for more than a decade.

Particularly dangerous are the integration processes of terrorism and organized crime, which have become so strong that it allows the criminal authorities to carry out actions that may cause socio-economic complications. This was most characteristic in the Autonomous Republic of Crimea, where a notable destabilizing factor was the activity of two criminal clans, "Shoes" and "Sailem" [1, p. 78].

A specific feature that potentially transforms the scale of terrorism in the country is the problem of illegal storage and trafficking of weapons, explosives and other items that can be used for terrorist crimes. The population illegally owns a large number of firearms. In 1995-1998, the police seized 6.5 thousand units, and more than 5.5 thousand units were wanted for. The main ways of acquiring firearms are thefts from storage 
facilities, export from military conflict zones, receipts from abroad, and home-made production. The storage of unregistered weapons by members of illegal paramilitary groups poses great danger. The trend of committing terrorist crimes using improvised explosive devices is becoming more and more threatening. In 1995-1996, more than 560 such crimes were committed in Ukraine resulting in 90 persons killed (15 representatives of government structures), 218 were injured (19 respectively) [1, p. 85]. These crimes are usually committed by criminal elements struggling for the redistribution of spheres of influence to eliminate competitors in illegal business, as well as eliminate or intimidate representatives of local or state authorities.

The issue of nuclear and environmental terrorism remains unresolved for Ukraine. The country features high concentration of nuclear power plants and vast number of environmentally hazardous facilities. Some of them are in a poor technical condition. The volume of telephone terrorism does not decrease. Anonymous calls are received about possible explosions in transport industry, educational institutions, and public places, as well as at nuclear, thermal power plants, and other energy facilities. E.g., officers of the Security Service detained a resident of Slavutych, who in December 1994 via anonymous calls threatened to blow up the Chernobyl Nuclear Power Plant and demanded 2 million US dollars. In 1995 the Security Service of Ukraine, in cooperation with other law enforcement agencies, prevented 5 attempts to illegally acquire, store and export nuclear and radioactive materials abroad [1, p. 97].

In today's conditions, Ukraine cannot adequately counter the growing wave of terrorism. Serious difficulties are revealed on a whole range of issues related to legal, organizational, operational, and other areas of countering various forms of terrorism. The system of social values of the population is distorted: mechanisms of ordering and regulating relations that directly or indirectly affect the foundations of the state and socialpolitical system are not effective enough; new factors have emerged that contribute to criminal acts (social stratification of society, aggravation of political struggle, unemployment and social insecurity, legal nihilism, inter-religious issues).

In Ukraine the issue of terrorism requires careful research not only by representatives of the legal community but also sociology, political science, social, individual psychology, and other fields of science. The lack of scientific and journalistic literature that covering issues of terrorism, the lack of a scientifically-based definition of the state of terrorism and forecasts of its development in Ukraine reduces the severity of 
the issue, narrows down the potential to develop and implement anti-terrorist measures in the legislative, law enforcement, and national spheres. Raising the issue of terrorism prevention in Ukraine as part of the tasks of the law enforcement system, we must first note the need to prevent this crime in the national law. There are acute problems of preventing terrorism in our national legislation. Firstly, there is no dedicated legal act that would solve the problems of terrorism prevention; secondly, there is no special article in the criminal legislation that would provide for responsibility for committing a terrorist act. The dedicated law on counter-terrorism would allow to legislate the organizational and legal basis for combating terrorism, define it as a political and socioeconomic phenomenon, and legislate state law enforcement agencies responsible for preventing and suppressing terrorist attacks.

In order to improve national legislation in this area a draft anti-terrorist law ("On the organizational and legal basis for combating terrorism") has been developed by the team of the Interdepartmental Research Center for Combating Organized Crime. During the transition phase, the version of the draft Law of Ukraine "On strengthening the fight against terrorism", developed by a group of experts, which included representatives of the Security Service of Ukraine, Ministry of Justice, Institute of State and Law of the National Academy of Sciences of Ukraine is acceptable. The draft law provides for amendments and additions to the criminal and criminal procedure legislation, which is especially important, emphasizes terrorism as an independent crime with the definition of a terrorist group and a terrorist organization. Amendments to the "Hostage Taking" Article of the Criminal Code [3]. The draft law defines terrorism as the exercise or threat of an explosion, arson or other act that endangers human life and health, and the threat of grave consequences, if committed with the aim of compelling state bodies, local government or international organizations or their representatives to perform or refrain from performing any act or aimed at provoking war, armed conflict, the emergence of international complications or destabilizing the situation in the country. Since terrorism is a multilevel and large-scale phenomenon, the forms of its manifestation differ both in content characteristics and in the scope of implementation - therefore, the criminal law's phenomenon of terrorism should have a more definitive character and clear boundaries. This is necessary due to a certain formality of law and the obligation to establish sufficient grounds for criminal prosecution. In the criminal law, such a basis is an entirety of corpus delicti, which should clearly and precisely characterize such a phenomenon of life as a 
crime. A positive aspect is the identification of the objective side in the structure of terrorism - threat of committing a crime. The threat of violent extremist actions is highlighted as a new form of terrorism. The need for the inclusion of this form is based on the fact, that, firstly, it is necessary to criminalize cases of 'warning explosions', arson not posing a threat of loss of life or significant material damage by which the perpetrators however, intend to demonstrate the substantiality of their threats; secondly, on the need to strengthen accountability for a dangerous crime such as terrorism by transferring the end of the crime from the practical actions to the previous stage i.e. declaring a serious threat.

The next positive aspect of the draft law is the designation of a special subject of crime, whose age is set at 14 years. One of the qualifying characteristics of a certain type of terrorism is the establishment of a terrorist group and a terrorist organization or participation in it and the establishment or activity of such formations. It provides for the use of an auxiliary means of legal action containing an incentive norm of behavior of the guilty persons. This rule allows a person to voluntarily refuse committing acts of terrorism, without fear of being convicted of a criminal offence.

Given that terrorism has a number of objective and subjective characteristics similar to other types of crimes, it is important to identify, in specific cases, those characteristics that would help distinguish it from other crimes. First, terrorism should be distinguished from attacks on the life of a government official or public figure, and sabotage. These crimes are intended to undermine the constitutional order and security of the state, which is manifested in a different nature and content of the goal than terrorism. While terrorism is the perpetration of explosions, arson, or other actions aimed at intimidating (in the broad sense of the word) of the population, whereas delicta publica are aimed to cause damage to the state as a form of social organization. In the case of sabotage, it is essential to cause material harm rather than physical [4].

This crime differs from attempts on a person in that causing harm to the said objects is a way of committing terrorism and shall be understood as an intermediate, but necessary stage in achieving the ultimate goal. The use of a generally dangerous method is associated not so much with the desire to afflict damage to the protected interests, but with the person's intention to achieve maximum effectiveness of their actions. In addition, in case of a murder, the victims are individually identified, and the perpetrators seek to cause death to such persons, while in the case of destruction or damage to property - to destroy or damage such property, and not the other. In the event of terrorism, the perpetrator is not 
interested in the victim or the nature and ownership of the property; it is important for them to intimidate the population, to induce the authorities to commit, or vice versa not to perform, the actions necessary for the perpetrator [5].

In the national anti-terrorist legislation, it would be wrong not to use such consolidating, public and state institutions, the influence of which is a commonality of approaches to the issue of innocent victims of terrorism. Since terrorism seeks effect of a specific action on the decision-making authorities as well as the relevant segments of the population influencing the decision-making process by their response, in the event of terrorism, there is a gap between the direct victim of violence and the targeted group, the aim of violence. Therefore, the presence of innocent victims, as well as the danger of their occurrence, is a characteristic feature of modern terrorism [6].

To sum it up, it is impossible to neglect positive trends in the adoption of timely legislative acts. The President of Ukraine, Leonid Kuchma, signed a Decree 'On Ukraine's Participation in the Eurasian Group on Combating Money Laundering and Financing of Terrorism' in 2004.

The Decree supports the proposal of the Cabinet of Ministers of Ukraine regarding Ukraine's participation as an observer in the Eurasian Group on Combating Money Laundering and Financing of Terrorism.

According to the document, the State Department for Financial Monitoring is responsible for cooperation with the Eurasian Group on Combating Money Laundering and Financing of Terrorism and representing the interests of Ukraine in this organization [7].

The strategic course of Ukraine towards EU integration and the entry of the national science into the European and global scientific space allowed the Ukrainian legislators, together with scientists, to make a significant step towards the development of counterterrorism and anti-terrorist security legislation.

The provisions of the laws of Ukraine set basic terms, principles and organizational basis of fight against terrorism; range of subjects of fight against terrorism and their powers; regimes, legal basis of anti-terrorism activities; general principles of observance of the rights and legitimate interests of citizens while ensuring anti-terrorism security, and establish responsibility for crimes related to terrorist activity, and outline the general principles of pre-trial investigation.

In order to assess the status and readiness of counter-terrorism actors to perform the 
tasks of preventing, responding to and deterring acts of terrorism and minimizing their consequences, the state of their personnel, financial, logistical and other types of support, as well as the existing capabilities to effectively respond to terrorist threats, Decree No.506 of the President of Ukraine V. Zelensky of July 9, 2019 approved the procedure for conducting an inspection of the national system for combating terrorism. The United Nations' Global Counter-Terrorism Strategy adopted by the UN General Assembly on September 8, 2006, is an international instrument that defines a common strategic approach to combating terrorism on a global scale.

International statutory instruments consented to by the Verkhovna Rada of Ukraine, establish general principles of international cooperation in the field of preventing and countering terrorism, define crimes related to terrorism, and also impose the obligation to promote awareness of the existence, causes, severity of terrorist crimes, and the threat they pose.

At the present stage, the legislation of Ukraine needs further systematization, codification, and improvement, introduction of protective levers aimed at identifying and eliminating the causes and conditions that give rise to terrorism, exposing signs of terrorist manifestations, preventing their transformation into real actions. [8, 9, 10].

Conclusions Further expansion of the scope of research and development of methods, models, techniques for analyzing and assessing the risks of terrorist situations, forecasting their development and prevention will help to improve the efficiency of the counter-terrorism measures.

\section{References}

1. V.Antipenko. Modern Terrorism: State and Prevention Capabilities (Forensic research). - K.: 1998. - p. 50-97.

2. E.Lyakhov. The policy of terrorism is a policy of violence and aggression. International relations, Moscow, 1987. - p. 90.

3. Scientific and practical commentary of the Criminal Code of Ukraine (On the status of legislation and decisions of the Plenum of the Supreme Court of Ukraine on January 1, 1997) - K.: 1997. - p. 235.

4. Scientific and practical commentary of the Criminal Code of Ukraine (On the status of legislation and resolutions of the Plenum of the Supreme Court of Ukraine as of January 1, 1997) - K.: 1997. - p. 240.

5. Scientific and practical commentary of the Criminal Code of Ukraine (On the status of legislation and resolutions of the Plenum of the Supreme Court of Ukraine on January 1, 1997) - K.: 1997. - p. 243. 
6. E. Lyakhov. The policy of terrorism is a policy of violence and aggression. International relations, Moscow, 1987. - p. 45.

7. Decree of the President of Ukraine №1156 / 2004 of 30.09.2004 "On Ukraine's participation in the Eurasian Group on Combating Money Laundering and Terrorist Financing", access mode: https://zakon.rada.gov.ua/laws/show/1156/2004

8. Sergey Kudinov. Ways to improve the legal regulation of anti-terrorist security by the Security Service of Ukraine, 2019, access mode: http://pgpjournal.kiev.ua/archive/2019/2/45.pdf

9. Theoretical and practical aspects of anti-terrorist activity of special unit "SAS". URL: https://doi.org/10.32370/IAJ.2317

10. Specifics of activity of the armed executive body - GENDARMERIE. URL: https://doi.org/10.32370/IAJ.2112 